\title{
Habitat overlap and body condition in aquatic turtles: are there additive effects between invasive and native species?
}

\author{
Daniel Escoriza ${ }^{1, *}$, Pau Sunyer ${ }^{2}$, Santiago Poch ${ }^{1,2}$ and Dani Boix ${ }^{1}$ \\ ${ }^{1}$ GRECO, Institute of Aquatic Ecology, University of Girona, Girona, Spain \\ ${ }^{2}$ Fundació Emys, Carretera de Santa Coloma, Km 21, 17421 Riudarenes, Spain
}

Received: 28 October 2020 / Accepted: 5 January 2021

\begin{abstract}
Trachemys scripta (Reptilia, Emydidae) is among the most widespread invasive reptiles in the world. In general, it is assumed that this species has negative effects on native aquatic turtles based on experiments conducted under controlled conditions. Here, we analysed a 7-year time series (2013-2019) of data from captures of three species of turtles (two natives and one alien) from natural populations in the northeastern Iberian Peninsula. We evaluated (i) the interspecific spatial overlap and (ii) the correlation between the scaled mass index (SMI) of the native turtles and the abundance of $T$. scripta, including an interaction effect between the species. The analyses revealed that T. scripta has relatively low spatial overlap with Emys orbicularis but high overlap with Mauremys leprosa. Overall, the abundance of T. scripta was not associated with significant variations in the SMI of the native species, although for the female E. orbicularis, we detected a negative trend. The analyses also indicated that the abundance of T. scripta does not have an additive effect on the SMI of other turtles, even if there is a negative effect between native species. These findings suggested that the impact of T. scripta on other turtles could be density-dependent.
\end{abstract}

Keywords: Alien species / body mass / competition / Mediterranean / Trachemys scripta

\begin{abstract}
Résumé - Chevauchement de l'habitat et état corporel chez les tortues aquatiques: y a-t-il des effets additifs entre les espèces exogène et indigènes? Trachemys scripta (Reptilia, Emydidae) est l'un des reptiles exogènes les plus répandus au monde. En général, on considère que cette espèce a des effets négatifs sur les tortues aquatiques autochtones en se basant sur des expériences menées dans des conditions contrôlées. Nous avons analysé les données de 7 années (2013-2019) de captures de trois espèces de tortues (deux autochtones et une invasive) issues de populations naturelles dans le nord-est de la Péninsule Ibérique. Nous avons évalué (i) le chevauchement spatial interspécifique et (ii) la corrélation entre l'indice de masse des tortues autochotones et l'abondance de T. scripta, y compris l'effet d'interactions interspecifiques. Nos analyses montrent que T. scripta présente un chevauchement spatial relativement faible avec Emys orbicularis, et élevé avec Mauremys leprosa. L'abondance de T. scripta n'est pas associée à des variations significatives du SMI de l'espèce autochtone, même si dans le cas de femelles E. orbicularis, une tendance négative a été enregistrée. Nos résultats indiquent que l'abondance de T. scripta n'a pas d'effet additif sur le SMI des autres tortues, même s'il y a un effet négatif entre les espèces autochtones. Ces résultats suggèrent que l'impact de T. scripta sur les autres espèces de tortues pourrait dépendre de leur densité.
\end{abstract}

Mots-clés : Espèces exogène / masse corporelle / compétition / Méditerranéen / Trachemys scripta

\section{Introduction}

The spread of invasive species is one of the most compelling problems for biodiversity conservation globally (Early et al., 2016). The number of species recognized as

\footnotetext{
*Corresponding author: daniel_escoriza@hotmail.com
}

invasive is constantly increasing worldwide, possibly accelerated by human transport, deterioration of the quality of ecosystems, and global warming (Huang et al., 2011). Some of these species are particularly harmful to native communities, and this effect is derived from competition, predation, or the transmission of pathogens (Strayer, 2010).

An example of an invasive reptile is the pond slider, Trachemys scripta (Thunberg in Schoepff, 1792). This species 


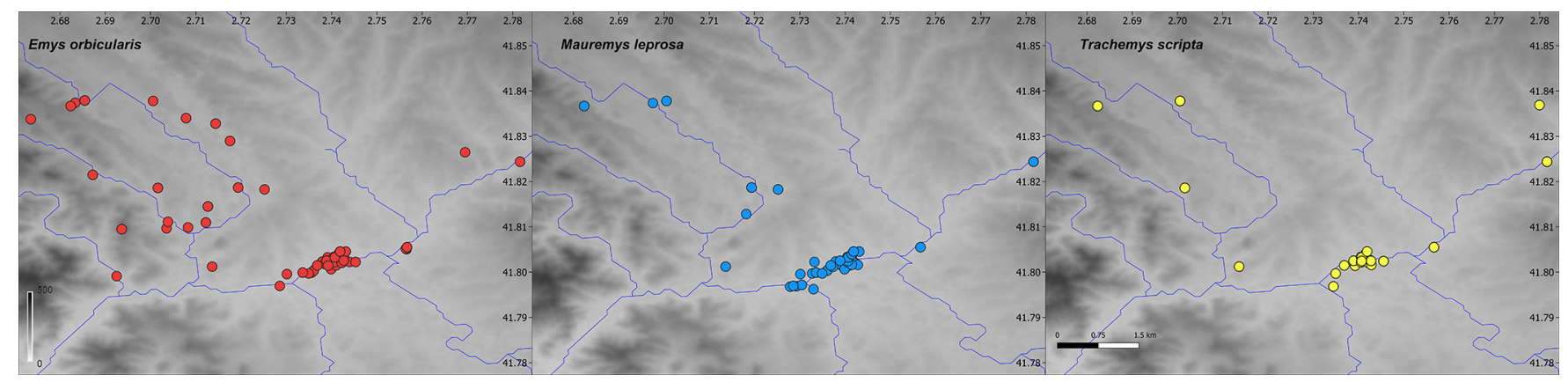

Fig. 1. Study region, showing the sites of captures by species superimposed on the terrain elevation (grey background) and main hydrological system (blue lines). Emys orbicularis (red circles); Mauremys leprosa (sky-blue circles); Trachemys scripta (yellow circles).

was extensively commercialized as a pet in the last decades of the 20th century and has established breeding populations in numerous tropical and subtropical regions around the world (Burgin, 2006; Ramsay et al., 2007; Tortato et al., 2014). Once established, T. scripta may have negative effects on native turtle species due to competitive interference in dietary or thermoregulatory resources or by acting as a disease vector (Cadi and Joly, 2003; Lee and Park, 2010; Iglesias et al., 2015; Balzani et al., 2016). Interactions with other species of aquatic turtles are apparently unbalanced in favour of $T$. scripta due to its larger size and aggressive behaviour (Polo-Cavia et al., 2009, 2011). However, negative effects from populations of this species on native freshwater turtles have not been reported in all regions where it appears (Wang et al., 2013).

In this study, we evaluated the patterns of spatial overlap of T. scripta with two species of native turtles, Emys orbicularis (Linnaeus, 1758) and Mauremys leprosa (Schweigger, 1812) in the upper Tordera basin (northeastern Spain). Preliminary research suggested that these three species coexist in the same aquatic habitats, but it is not known how they overlap spatially (Escoriza et al., 2020). In this sense, we expected that two types of patterns may appear: spatial partition (i.e., low overlap) derived from the displacement of native species from the optimal habitats or high overlap if the alien species become established occupying vacant resource niches (Gebauer et al., 2019). The low overlap pattern characterizes the contact between ecologically analogous species, but being one of them a superior competitor (Mori et al., 2018). A high overlap occurs when the species are syntopically distributed. This pattern characterizes the contact between native and alien species which use relatively similar environmental niches, but are segregated at trophic level (Alves et al., 2017).

We also investigated the possible effects of T. scripta on the body condition of native species based on data obtained from natural populations. If the alien and native species share trophic resources, the presence of an invasive species may be correlated with a marked decrease in the body condition of the native populations (Gurnell et al., 2004). This effect has been demonstrated in the case of the coexistence between T. scripta and E. orbicularis, but under controlled conditions with artificially high densities (Cadi and Joly, 2004). We expected (hypothesis i) to find some level of habitat partitioning that could explain the presence of the three species within the same basin (Segurado and Figueiredo, 2007; Escoriza, 2018). We also expected (hypothesis ii) that the abundance of the invasive turtle would negatively affect the body condition of the native species both by itself and synergistically with the native species because these turtles widely overlap in their trophic niches (Díaz-Paniagua et al., 2011).

\section{Material and methods}

\subsection{Study system}

The study region is the upper basin of the Tordera River, northeastern Spain (Fig. 1). The climate of the basin is warmMediterranean (Köppen-Geiger classification), with a period of summer aridity from 60 to 90 days per year (Riba et al., 1980). In this region, breeding populations of three species of aquatic turtles, two natives (E. orbicularis and M. leprosa), and one alien (T. scripta) appear (Fig. 1). Trachemys scripta has been detected regularly since the late 1990s, and its reproduction has been observed since the beginning of the 21 st century (Poch et al., 2020). Other alien turtle species have been located in the area, e.g., Mauremys mutica (Cantor, 1842), although their presence is occasional and they have not established breeding populations (Poch et al., 2020).

We captured turtles using nets and floating baited net traps $(110 \times 50 \mathrm{~cm})($ Marchand and Litvaitis, 2004). The traps were placed in temporary ponds, permanent ponds, reservoirs, water treatment plants, and seasonal streams. Depending on the size of the aquatic habitat, the traps were separated by a minimum of $50 \mathrm{~m}$, totalling 69 site traps throughout the study region. We conducted surveys between 2013 and 2019 during the peak activity periods (March to July and September to November; Ramos et al., 2009). The strength of the interactions among the three turtle species was evaluated based on the percentage of the summed abundances by site trap (abundance ratio; StuartSmith et al., 2015).

The turtles were marked using unique combinations of holes drilled in the marginal scutes of the carapace (Plummer, 1979). We also determined the sex of each turtle, measured their total carapace lengths to the nearest millimetre, and weighted the specimens with a digital balance (accuracy $\pm 0.1 \mathrm{~g}$ ). The sex of the adult specimens was established using external dimorphic traits (Zuffi and Gariboldi, 1995; Muñoz and Nicolau, 2006). We classified E. orbicularis specimens that did not show secondary sexual traits and with an axial carapace length smaller than $103 \mathrm{~mm}$ as juveniles (Ramos et al., 2009; Escoriza et al., 2020). In M. leprosa and T. scripta, 
Table 1. Turtle captures in the upper Tordera basin, during the sampling period. N, percentage of total captures. Sex ratio, (males/ males + females). Water body type: pond, stream, and artificial (irrigation canals and reservoirs). Traps, percentage of traps with captures. SMI, scaled mass index mean \pm standard deviation $(\mathrm{M}=$ males, $\mathrm{F}=$ females $)$.

\begin{tabular}{lllll}
\hline & Emys orbicularis & Mauremys leprosa & Trachemys scripta & Other species \\
\hline Category & Native & Native & Alien & Alien \\
N & $56.4 \%$ & $37.0 \%$ & $6.0 \%$ & $0.5 \%$ \\
Sex ratio & $48.6 \%$ & $53.9 \%$ & $42.9 \%$ & - \\
Pond & $63.8 \%$ & $46.9 \%$ & $74.4 \%$ & $28.6 \%$ \\
Stream & $25.6 \%$ & $17.1 \%$ & $4.3 \%$ & $57.1 \%$ \\
Artificial & $10.5 \%$ & $35.9 \%$ & $21.4 \%$ & $14.3 \%$ \\
Traps & $76.8 \%$ & $59.4 \%$ & $34.8 \%$ & $5.9 \%$ \\
SMI $_{M}$ & $0.913 \pm 0.154$ & $2.011 \pm 0.225$ & - & - \\
SMI $_{\mathrm{F}}$ & $1.022 \pm 0.160$ & $2.274 \pm 0.390$ & - & - \\
\hline
\end{tabular}

we assumed that the minimum adult carapace length was $90 \mathrm{~mm}$ and $100 \mathrm{~mm}$ respectively (da Silva et al., 1990; Mitchell and Pague, 1990).

\subsection{Data analyses}

We evaluated (i) the spatial overlap between the three species of freshwater turtles with breeding populations in the region and (ii) the variation in the body condition of native species depending on the relative abundances of other species of turtles. The spatial overlap was estimated by calculating the utilization distribution overlap index (UDOI; Fieberg and Kochanny, 2005) for each site trap. This index is recommended for estimating the shared use of space among several species (Robert et al., 2012). UDOI ranges from zero (no overlap) to one (full overlap, with the species evenly distributed), being greater than one when the species show high overlap but are not evenly distributed (Fieberg and Kochanny, 2005). UDOI was estimated using the adehabitatHR package (Calenge, 2006) in the $\mathrm{R}$ environment ( $\mathrm{R}$ Development Core Team, 2020).

The body condition of the specimens of native turtles was estimated using body mass index. The body mass index was calculated following the procedure proposed by Peig and Green (2009), which corrected body mass for body size (scaled mass index, SMI). The intra and interspecific variation in the SMI of the native turtles was represented using violin plots, each showing a kernel density plot, ranging from the maximum to the minimum value. SMI was standardized using Tukey's ladder of powers transformation (Pek et al., 2017). SMI was included as a response variable in a Generalized Linear Mixed Model (GLMM), which included fixed effects (abundance ratio, sex category, survey period, and site) and random effects. The survey period was defined as a categorical variable encompassing sampling intervals of 14 days. The sites were the sampled aquatic habitats including irrigation canals, ponds, or stream sections. We included the specimen codes nested within sites as a random effect in the GLMM to account for pseudoreplication. The abundance ratio was included as an interaction term to test for additive effects between species. The model fit was compared using ANOVA-like tests and the
Table 2. Intensity of spatial overlap (UDOI) among three turtle species in the upper Tordera basin. Values of UDOI $=1$ indicate a high spatial overlap, being greater than one when the species show high overlap but are not evenly distributed.

\begin{tabular}{llll}
\hline & $\begin{array}{l}\text { Emys } \\
\text { orbicularis }\end{array}$ & $\begin{array}{l}\text { Mauremys } \\
\text { leprosa }\end{array}$ & $\begin{array}{l}\text { Trachemys } \\
\text { scripta }\end{array}$ \\
\hline Emys orbicularis & 1.441 & & \\
Mauremys leprosa & 0.629 & 2.096 & \\
Trachemys scripta & 0.453 & 1.655 & 3.478 \\
\hline
\end{tabular}

Akaike information criterion (Bates et al., 2015). These calculations were conducted using the lme4 package (Bates et al., 2015) in the R environment.

\section{Results}

During the sampling period, 1339 turtle specimens were captured, of which the native species represented $93.4 \%$ (Tab. 1). Emys orbicularis was the most widespread species and the one that appeared most frequently in the captures (Tab. 1 and Fig. 1). The surveys also indicated that the turtle species occupy aquatic habitats differently, with $T$. scripta tending to appear more frequently in large permanent ponds and artificial habitats, such as water reservoirs and irrigation canals (Tab. 1). The UDOI estimations showed that E. orbicularis has a moderate spatial overlap with $M$. leprosa and T. scripta, while M. leprosa showed high spatial overlap with T. scripta (Tab. 2).

Females of E. orbicularis and M. leprosa showed higher SMI values than the males (E. orbicularis: estimate $=-0.186$, $\mathrm{df}=642, p<0.001 ;$ M. leprosa estimate $=-0.646, \mathrm{df}=395$, $p<0.001$ ) (Tab. 1 and Fig. 2), so both sexes were also evaluated separately. In E. orbicularis, for both sexes, the model (M2) including the interaction of $M$. leprosa with $T$. scripta was not significantly better than the model (M1) evaluating the effect of both species separately $\left(\mathrm{AIC}_{\mathrm{M} 1}=144, \mathrm{AIC}_{\mathrm{M} 2}=146\right.$, $\left.\chi^{2}=0.135, p=0.714\right)$. The SMI showed a significant negative association with $M$. leprosa (Tab. 3). For the males, the model (M2) including the interaction of M. leprosa with T. scripta 


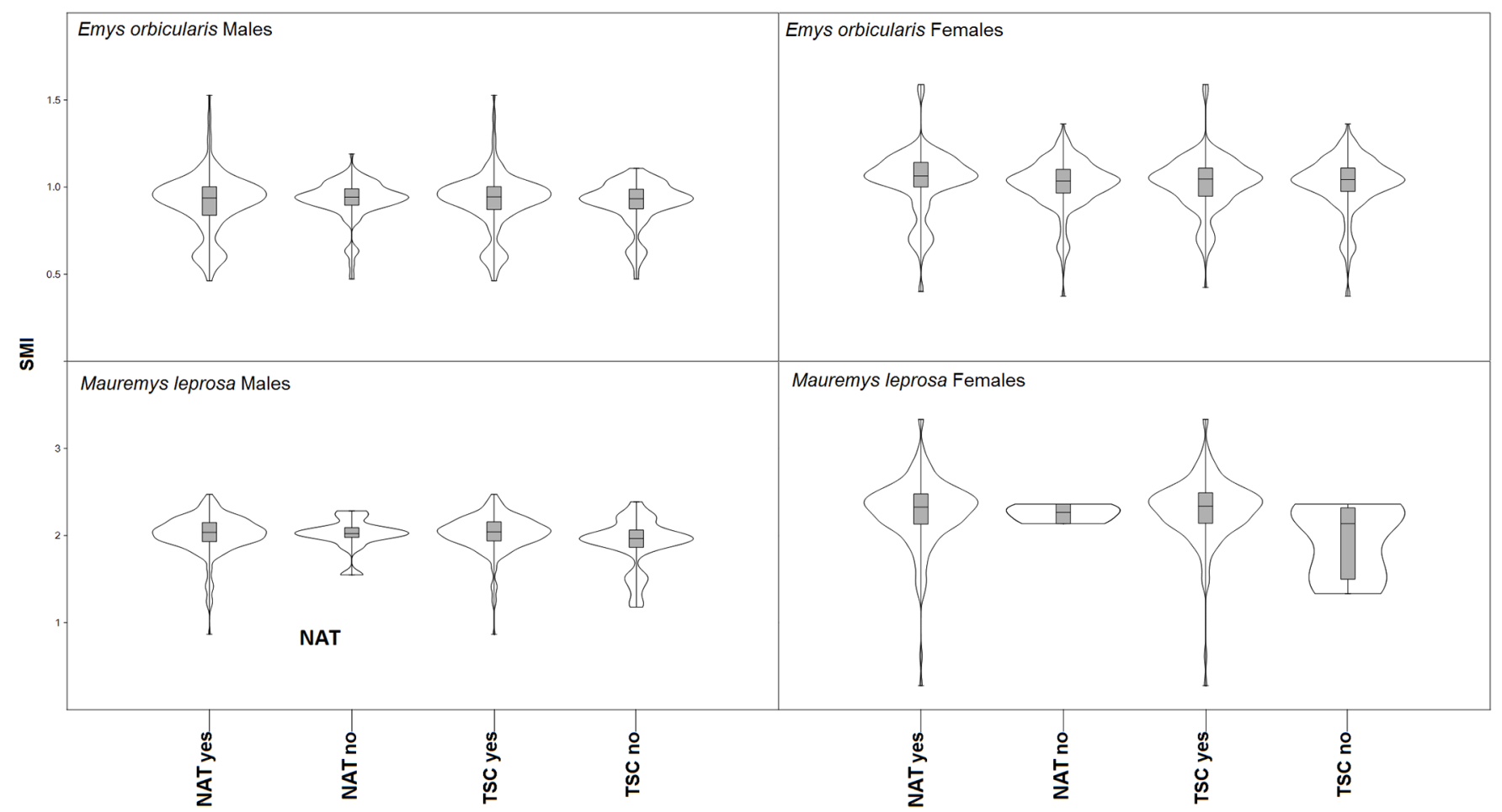

Fig. 2. Violin density plots, showing the association between the scaled mass index (SMI) and the presence of other turtle species. The grey box represented the 25-75 quartiles and the violin shape the kernel density plot, ranging from the maximum to the minimum value. NAT, native; TSC, T. scripta.

Table 3. Generalized Linear Mixed Model results assessing the variation of the scaled mass index (SMI) in adult E. orbicularis from the upper Tordera basin. Significant variables at alpha $=0.1$ are highlighted in bold font.

\begin{tabular}{|c|c|c|c|c|c|}
\hline & & T. scripta & M. leprosa & Period & Site \\
\hline \multirow[t]{3}{*}{ All } & $t$-value & -0.446 & -2.550 & -0.496 & 1.442 \\
\hline & $\mathrm{df}$ & 733 & 676 & 783 & 559 \\
\hline & $p$ & 0.656 & 0.011 & 0.620 & 0.150 \\
\hline \multirow[t]{3}{*}{ Males } & $t$-value & 0.016 & -0.800 & 1.599 & 1.019 \\
\hline & df & 323 & 301 & 350 & 253 \\
\hline & $p$ & 0.987 & 0.425 & 0.111 & 0.309 \\
\hline \multirow[t]{3}{*}{ Females } & $t$-value & -1.495 & -1.007 & -2.818 & 3.645 \\
\hline & df & 418 & 380 & 436 & 316 \\
\hline & $p$ & 0.136 & 0.315 & 0.005 & $<\mathbf{0 . 0 0 1}$ \\
\hline
\end{tabular}

was not significantly better than the model (M1) evaluating the effect of both species separately $\left(\mathrm{AIC}_{\mathrm{M} 1}=-37, \mathrm{AIC}_{\mathrm{M} 2}=-35\right.$, $\left.\chi^{2}=0.018, p=0.895\right)$. For the males, the SMI did not show significant associations with any of the predictors (Tab. 3). For the females, the model (M2) including the interaction of $M$. leprosa with T. scripta was not significantly better than the model (M1) evaluating the effect of both species separately $\left(\mathrm{AIC}_{\mathrm{M} 1}=121, \mathrm{AIC}_{\mathrm{M} 2}=122, \chi^{2}=0.731, p=0.393\right)$. The SMI of the females showed significant associations with period and site (Tab. 3). In the females of E. orbicularis, the associations with other species of turtles showed a negative trend, without achieving statistical significance (Tab. 3).

In M. leprosa, for both sexes, the model (M2) including the interaction of E. orbicularis with $T$. scripta was not significantly better than the model (M1) evaluating the effect of both species separately $\left(\mathrm{AIC}_{\mathrm{M} 1}=912, \quad \mathrm{AIC}_{\mathrm{M} 2}=914\right.$, $\chi^{2}=0.069, p=0.792$ ). The SMI showed a significant negative association with E. orbicularis (Tab. 4). For the males, the model (M2) including the interaction of $M$. leprosa with T. scripta was not significantly better than the model (M1) evaluating the effect of both species separately $\left(\mathrm{AIC}_{\mathrm{M} 1}=1603\right.$, $\left.\mathrm{AIC}_{\mathrm{M} 2}=1605, \chi^{2}=0.016, p=0.900\right)$. For the males of M. leprosa, the SMI showed a marginally significant negative association with E. orbicularis (Tab. 4). For the females, the model (M2) including the interaction of E. orbicularis with T. scripta was not significantly better than the model (M1) evaluating the effect of both species separately $\left(\mathrm{AIC}_{\mathrm{M} 1}=598\right.$, $\left.\mathrm{AIC}_{\mathrm{M} 2}=596, \chi^{2}=2.969, p=0.085\right)$. For the females of 
D. Escoriza et al.: Knowl. Manag. Aquat. Ecosyst. 2021, 422, 2

Table 4. Generalized Linear Mixed Model results assessing the variation of the scaled mass index in adult M. leprosa from the upper Tordera basin. Significant variables at alpha $=0.1$ are highlighted in bold font.

\begin{tabular}{|c|c|c|c|c|c|}
\hline & & T. scripta & E. orbicularis & Period & Site \\
\hline \multirow{3}{*}{ All } & $t$-value & 0.160 & -4.057 & -0.229 & -0.466 \\
\hline & df & 403 & 409 & 310 & 336 \\
\hline & $p$ & 0.873 & $<0.001$ & 0.819 & 0.641 \\
\hline \multirow[t]{3}{*}{ Males } & $t$-value & -0.579 & -1.680 & 0.392 & -0.071 \\
\hline & $\mathrm{df}$ & 252 & 250 & 157 & 215 \\
\hline & $p$ & 0.563 & 0.094 & 0.696 & 0.944 \\
\hline \multirow[t]{3}{*}{ Females } & $t$-value & 0.200 & -3.239 & -1.301 & 0.026 \\
\hline & df & 150 & 147 & 119 & 135 \\
\hline & $p$ & 0.842 & 0.002 & 0.196 & 0.979 \\
\hline
\end{tabular}

M. leprosa, the SMI showed a significant negative association with E. orbicularis (Tab. 4).

\section{Discussion}

This study evaluated the patterns of spatial overlap in three species of aquatic turtles, two native and one alien, and the possible effects of the abundance of other turtle species on body condition. Our findings showed spatial overlap between the three species, indicating that the invasive species has not established populations in vacant habitat patches. However, T. scripta is unevenly distributed in the study region, mainly confined at large permanent ponds or irrigation canals, showing relatively dense populations only in two aquatic habitats near villages. This colonization pattern is typical of this species, which begins its expansion in highly altered habitats, from where it may expand to adjacent habitats, in some cases dominated by native turtles (Thomson et al., 2010; Di Santo et al., 2017).

Emys orbicularis is the turtle species that displays the highest occupation of aquatic habitats, but the spatial analysis indicated that its overlap with $T$. scripta is relatively low. This pattern could be the result of differences in habitat quality rather than species interactions. In the study region, E. orbicularis is the only turtle species that occupies forest ponds (Escoriza et al., 2020). These ponds typically have relatively little sun exposure and low water temperatures (Werner and Glennemeier, 1999). Emys orbicularis is well adapted to this type of environment, as it displays activity at lower air temperatures than other turtles, being active at temperatures above $9{ }^{\circ} \mathrm{C}$ compared with $14^{\circ} \mathrm{C}$ in $M$. leprosa (Ramos et al., 2009; Salvador, 2014). Trachemys scripta remains totally inactive below $10^{\circ} \mathrm{C}$ and is not usually captured in baited traps when temperatures are below $20^{\circ} \mathrm{C}$ (Ernst et al., 1994).

Our results revealed that the populations of native turtles coexisting with $T$. scripta do not show significantly lower SMI values (including the absence of synergistic effect), with the possible exception of the subpopulation of E. orbicularis females, for which we found a negative trend close to statistical significance. These results contrast with the findings of previous studies conducted in captivity, in which E. orbicularis exposed to T. scripta showed a significant weight decrease (Cadi and Joly, 2004). However, these experiments were conducted under artificial densities in conditions that do not appear in wild populations (Cadi and Joly, 2004). Our study was based on data from natural populations with lower and unmanaged densities, which could partly explain the discrepancies. On the other hand, natural populations of turtles are exposed to other factors that influence the variability in the SMI, such as the year season (due to the effects of oviposition in females, hibernation or aestivation) or habitat quality (Kennett and Georges, 1990; Litzgus and Mousseau, 2006). These factors also affect our target populations and would explain the variability between sampling periods and habitats that is observed in the female subpopulation of E. orbicularis.

We cannot rule out that negative effects on body condition may appear if the populations of T. scripta increase in the future or if this species expands its range due to global warming (Teillac-Deschamps et al., 2008). Negative effects on native species may not appear until a density threshold is reached, which would explain the low impact reported in other studies of wild populations (Chen, 2006; Robey et al., 2011; Wang et al., 2013). This density-dependent effect possibly explains the negative impact that appears reciprocally between both native species, because are more abundant in our study region. For this reason, we consider that eradication measures of alien populations of $T$. scripta are recommended, particularly taking into account the vulnerability of E. orbicularis in northeastern Spain (Keller and Andreu, 2002). The finding of other species of alien turtles during the surveys, such as Chrysemys picta (Schneider, 1783) or Mauremys reevesii (Gray, 1831), species with moderate to high invasion risk (Kopecký et al., 2013; Masin et al., 2014), also advises a greater control of the commercial trade to prevent they become invasive in the future.

Acknowledgements. Authorizations to field work and captures were provided by Servei de Protecció i Gestió de la Fauna de Catalunya. This project received funding from Land Stewardship ProgramDMA and Emys Foundation.

\section{References}

Alves GH, Figueiredo BR, Manetta GI, Sacramento PA, Tófoli RM, Benedito E. 2017. Trophic segregation underlies the coexistence of two piranha species after the removal of a geographic barrier. Hydrobiologia 797: 57-68. 
Balzani P, Vizzini S, Santini G, Masoni A, Ciofi C, Ricevuto E, Chelazzi G. 2016. Stable isotope analysis of trophic niche in two co-occurring native and invasive terrapins, Emys orbicularis and Trachemys scripta elegans. Biol Invasions 18: 3611-3621.

Bates D, Mächler M, Bolker B, Walker S. 2015. Fitting linear mixedeffects models using lme4. J Stat Softw 67: 1-48.

Burgin S. 2006. Confirmation of an established population of exotic turtles in urban Sydney. Aust J Zool 33: 379-384.

Cadi A, Joly P. 2003. Competition for basking places between the endangered European pond turtle (Emys orbicularis galloitalica) and the introduced red-eared slider (Trachemys scripta elegans). Can J Zool 81: 1392-1398.

Cadi A, Joly P. 2004. Impact of the introduction of the red-eared slider (Trachemys scripta elegans) on survival rates of the European pond turtle (Emys orbicularis). Biodivers Conserv 13: 2511-2518.

Calenge C. 2006. The package "adehabitat" for the R software: a tool for the analysis of space and habitat use by animals. Ecol Model 197: 516-519.

Chen, T. 2006. Distribution and status of the introduced red-eared slider (Trachemys scripta elegans) in Taiwan. In Koike F, Clout MN, Kawamichi M, De Poorter M and Iwatsuki K (eds) Assessment and Control of Biological Invasion Risks. Shoukadoh Book Sellers, Kyoto, Japan and IUCN, Gland, Switzerland, 187-195.

da Silva E, Cruz C, Sánchez JM, Lope F, Blasco M. 1990. El ciclo gonadal de Mauremys caspica leprosa. Resúmenes I Congreso Luso-Español Herpetologia, Lisboa, 92 p.

Díaz-Paniagua C, Pérez-Santigosa N, Hidalgo-Vila J, Florencio M. 2011. Does the exotic invader turtle, Trachemys scripta elegans, compete for food with coexisting native turtles? Amphibia-Reptilia 32: $167-175$.

Di Santo MP, Vignoli L, Carpaneto GM, Battisti C. 2017. Occurrence patterns of alien freshwater turtles in a large urban pond 'Archipelago' (Rome, Italy): Suggesting hypotheses on root causes. Lakes Reserv Res Manag 22: 56-64.

Early R, Bradley BA, Dukes JS, Lawler JJ, Olden JD, Blumenthal DM, Gonzalez P, Grosholz ED, Ibañez I, Miller LP, Sorte CJ. 2016. Global threats from invasive alien species in the twenty-first century and national response capacities. Nat Commun 7: 12485.

Ernst CH, Lovich JE, Barbour RW. 1994. Turtles of the United States and Canada. Washington DC, USA: Smithsonian Institution Press, $578 \mathrm{p}$.

Escoriza D. 2018. Patterns of occurrence of semi-aquatic reptiles in highly invaded Mediterranean rivers. NeoBiota 38: 23-35.

Escoriza D, Franch M, Ramos S, Sunyer-Sala P, Boix D. 2020. Demographics and survivorship in the European pond turtle (Emys orbicularis): a 31-year study. Herpetol Conserv Biol 15: 41-48.

Fieberg J, Kochanny CO. 2005. Quantifying home-range overlap: the importance of the utilization distribution. $J$ Wildlife Manag 69: $1346-1359$.

Gebauer R, Veselý L, Vanina T, Buřič M, Kouba A, Drozd B. 2019. Prediction of ecological impact of two alien gobiids in habitat structures of differing complexity. Can J Fish Aquat Sci 76: 1954-1961.

Gurnell J, Wauters LA, Lurz PW, Tosi G. 2004. Alien species and interspecific competition: effects of introduced eastern grey squirrels on red squirrel population dynamics. J Anim Ecol 73: 26-35.

Huang D, Haack RA, Zhang R. 2011. Does global warming increase establishment rates of invasive alien species? A centurial time series analysis. PLoS One 6: e24733.

Iglesias R, García-Estévez JM, Ayres C, Acuña A, Cordero-Rivera A. 2015. First reported outbreak of severe spirorchiidiasis in Emys orbicularis, probably resulting from a parasite spillover event. Dis Aquat Organ 113: 75-80.

Keller C, Andreu AC. 2002. Emys orbicularis. In Pleguezuelos JM, Márquez R, Lizana ME (eds) Atlas y Libro Rojo de Los Anfibios y Reptiles de España. Dirección General de la Conservación de la Naturaleza-Asociación Herpetológica Española. Madrid, Spain, $37-40$.

Kennett RM, Georges A. 1990. Habitat utilization and its relationship to growth and reproduction of the eastern long-necked turtle, Chelodina longicollis (Testudinata: Chelidae), from Australia. Herpetologica 46: 22-33.

Kopecký O, Kalous L, Patoka J. 2013. Establishment risk from pettrade freshwater turtles in the European Union. Knowl Manag Aquat Ecosyst 410: 02.

Lee HJ, Park DS. 2010. Distribution, habitat characteristics, and diet of freshwater turtles in the surrounding area of the Seomjin River and Nam River in southern Korea. J Ecol Environ 33: 237-244.

Litzgus JD, Mousseau TA. 2006. Geographic variation in reproduction in a freshwater turtle (Clemmys guttata). Herpetologica 62: 132-140.

Marchand MN, Litvaitis JA. 2004. Effects of habitat features and landscape composition on the population structure of a common aquatic turtle in a region undergoing rapid development. Conserv Biol 18: 758-767.

Masin S, Bonardi A, Padoa-Schioppa E, Bottoni L, Ficetola GF. 2014. Risk of invasion by frequently traded freshwater turtles. Biol Invasions 16: 217-231.

Mitchell JC, Pague A. 1990. Body size, reproductive variation, and growth in the slider turtle at the northeastern edge of its range. In: Gibbons J, ed. Life history and ecology of the slider turtle. Washington DC: Smithsonian Institution Press, 146-151.

Mori E, Zozzoli R, Mazza G. 2018. Coming in like a wrecking-ball: are native Eurasian red squirrels displacing invasive Siberian chipmunks? A study from an urban park. Urban Ecosyst 21: 975-981.

Muñoz A, Nicolau B. 2006. Sexual dimorphism and allometry in the stripe-necked terrapin, Mauremys leprosa, in Spain. Chelonian Conserv Biol 5: 87-92.

Peig J, Green AJ. 2009. New perspective for estimating body condition from mass/length data: the scaled mass index as an alternative method. Oikos 118: 1883-1891.

Pek J, Wong AC, Wong OC. 2017. Confidence intervals for the mean of non-normal distribution: transform or not to transform. Open J Stat 7: 405-421.

Poch S, Sunyer P, Pascual G, Boix D, Campos M, Cruset E, Quer-Feo C, Fuentes Miguel, Molina A, Porcar A, Pérez-Novo I, Pou-Rovira Q, Ramos S, Escoriza D. 2020. Alien chelonians in north-eastern Spain: new distributional data. Herpetol Bull 151: 1-5.

Polo-Cavia N, López P, Martín J. 2009. Interspecific differences in chemosensory responses of freshwater turtles: consequences for competition between native and invasive species. Biol Invasions 11: 431-440.

Polo-Cavia N, López P, Martín J. 2011. Aggressive interactions during feeding between native and invasive freshwater turtles. Biol Invasions 13: 1387-1396.

R Development Core Team. 2020. R package vs 4.0.0 R Foundation for Statistical Computing. https://cranr-projectorg. Accessed 25 June 2020

Ramos S, Franch M, Llorente GA, Montori A. 2009. Morphometry and biological cycle of a European Pond Turtle. Emys orbicularis) population from north-eastern Spain. Rev Esp Herpetol 23: $117-128$. 
Ramsay NF, Ng PK, O'Riordan RM, Chou LM. 2007. The red-eared slider (Trachemys scripta elegans) in Asia: a review. In: Gherardi $\mathrm{F}$ (ed.). Biological invaders in inland waters: profiles, distribution, and threats. Springer, Dordrecht, 161-174.

Riba O, De Bolós O, Panareda JM, Nuet J, Gosalbez J. 1980. Geografia física dels Països Catalans: Principat de Catalunya, Pais Valencià i Illes Balears. Ketres, Barcelona, Spain, 226 p.

Robert K, Garant D, Pelletier F. 2012. Keep in touch: does spatial overlap correlate with contact rate frequency? J Wildl Manag 76: 1670-1675.

Robey J, Burgin S, Hitchen D, Ross G. 2011. Status of an urban feral Red-Eared Slider (Trachemys scripta elegans) population in Sydney a decade on. Aust J Zool 35: 822-825.

Salvador A. 2014. Fauna Ibérica Vol 10 Reptiles. Consejo Superior de Investigaciones Científicas, Madrid, Spain, 1367 p.

Segurado P, Figueiredo D. 2007. Coexistence of two freshwater turtle species along a Mediterranean stream: the role of spatial and temporal heterogeneity. Acta Oecol 32: 134-144.

Strayer DL. 2010. Alien species in fresh waters: ecological effects, interactions with other stressors, and prospects for the future. Freshw Biol 55: 152-174.

Stuart-Smith RD, Edgar GJ, Stuart-Smith JF, Barrett NS, Fowles AE, Hill NA, Cooper AT, Myers AP, Oh ES, Pocklington JB, Thomson RJ. 2015. Loss of native rocky reef biodiversity in Australian metropolitan embayments. Mar Pollut Bull 5: 324-332.
Teillac-Deschamps P, Delmas V, Lorrillière R, Servais V, Cadi A, Prévot-Julliard AC. 2008. Red-eared Slider Turtles (Trachemys scripta elegans) introduced to french urban wetlands an integrated research and conservation program. Herpetol Conserv 3: 535-537.

Thomson RC, Spinks PQ, Shaffer HB. 2010. Distribution and abundance of invasive red-eared sliders (Trachemys scripta elegans) in California's Sacramento River Basin and possible impacts on native western pond turtles (Emys marmorata). Chelonian Conserv Biol 9: 297-302.

Tortato MA, Bressan RF, Kunz TS. 2014. Reproduction of two exotic species of Trachemys Agassiz, 1857 (Testudines, Emydidae) at Parque Estadual da Serra do Tabuleiro, state of Santa Catarina, southern Brazil. Herpetol Notes 7: 11-15.

Wang J, Shi HT, Hu SJ, Ma K, Li C. 2013. Interspecific differences in diet between introduced red-eared sliders and native turtles in China. Asian Herpetol Res 4: 190-196.

Werner EE, Glennemeier KS. 1999. Influence of forest canopy cover on the breeding pond distributions of several amphibian species. Copeia 5: 1-2.

Zuffi MA, Gariboldi A. 1995. Sexual dimorphism of the European pond terrapin, Emys orbicularis (L., 1758) from Italy. In: Llorente GA, Montori A, Santos X, Carretero MA (eds). Proceedings of the 7th Ordinary General Meeting of the Societas Europaea Herpetologica (SEH). Scientia Herpetologica, Barcelona, Spain, 124-129.

Cite this article as: Escoriza D, Sunyer P, Poch S, Boix D. 2021. Habitat overlap and body condition in aquatic turtles: are there additive effects between invasive and native species? Knowl. Manag. Aquat. Ecosyst., 422, 2. 